\title{
COVID-19 pandemic is a stimulus for sustainable development of rural areas and labor markets
}

\author{
Oleg Chekmarev ${ }^{1, *}$, Alexander Manilov ${ }^{1}$, Akhmedkhan Ulimbashev ${ }^{1}$ and Svetlana \\ Timoshenko ${ }^{2}$ \\ ${ }^{1}$ Saint Petersburg State Agrarian University, Saint Petersburg, Pushkin, Russia \\ ${ }^{2}$ Federal State Budgetary Institution of Science "St. Petersburg Federal Research Center Russian \\ Academy of Sciences ", Saint Petersburg, Russia
}

\begin{abstract}
Research background: The COVID-19 pandemic has exacerbated the challenges of maintaining the sustainability of urban agglomerations and provides a fresh look at the feasibility of developing rural areas and their labor markets. This situation stimulates the authorities, the population and business to pay attention to the benefits of the development of rural areas Purpose of the article: The main goal of the presented article is assessment of the COVID-19 pandemic impact on the stimulus and opportunities for the sustainable development formulation of rural areas and its labor markets.

Methods: For research statistical materials and the results of scientific research by Russian and foreign scientists on the problems of the development of rural areas and their labor markets in the pre-covid period are used. The dynamics and dependence of the incidence of COVID-19 on the population's residence in rural and urban areas in certain regions of Russia, the growth in demand for suburban real estate, the problems of limiting migration during the development of the coronavirus pandemic and changes in labor markets that stimulate the relocation of the population to rural areas are investigated.

Findings \& Value added: The results indicate that the COVID-19 pandemic has created stimulus for the intensive development of rural areas, both on population of the countries and authorities. To maintain the positive trends, the state authorities is needed to invest in sustainable development infrastructure of rural areas, as well as the legislative consolidation of the rights and obligations of freelancers.
\end{abstract}

Keywords: labor markets; rural areas; COVID-19; sustainable development

JEL Classification: $A 14 ; B 16 ; O 15 ; Q 01$

\footnotetext{
* Corresponding author: oleg1412@mail.ru
} 


\section{Introduction}

In recent decades the problems of rural areas development occur both in developed and developing countries and have acquired a global reach (Caunedo et al., 2021). Many international organizations, including FAO (FAO, 2018), declare the prevalence, relevance of these problems, as well as possible ways to solve them. The main issues that need to be addressed to rural areas are the limited employment opportunities and the relatively disposable incomes (especially wages), and the underdevelopment of social and production infrastructure (Lang et al., 2021; Angelov \& Waldenström, 2021; Wosiek, 2020). These unresolved issues leads to the depopulation of rural areas, their "desertification", the non-use of land potential even in developed countries (FAOSTAT Land Use, 2021, Brawn \& Mirzabayev, 2016; Kuroda, 2019; Sauter et al., 2019; Wosiek, 2020). From the point of view of the theory of sustainable development, rural area lost to urban agglomerations in relation to individual elements of the social and especially economic components of the triad.

At the same time, many researchers pay attention to the positive effects of rural development such as country's food security, the urban agglomerations environmental buffer, recreation zones, a migration labor both at the state and global levels, etc. (Colucci et al., 2015; Wosiek, 2020). Even in before the COVID-19 pandemic, the rural lifestyle and settlement was attractive to a significant part of the urban population. The opportunity to work on the land (even within the framework of small land plots), raising children away from urban temptations, a measured but active lifestyle and other advantages of living in rural areas created a potential request for relocation to rural areas (Zvyagintsev \& Neuvazhaeva, 2015). However, this request was practically not implemented due to the problems of the village mentioned above.

The ongoing global processes of urbanization and migration from rural areas (FAOSTAT Land Use, 2021; Rosstat, 2021) force individual members of the government of some countries, including Russia, to consider these processes as global trends and focus on the development of urban agglomerations. And this is despite of the fact that, in general, states have their own programs for the development of rural areas (Ministry of Economic Development of the Russian Federation, 2011). But in case of Russia, these programs are mainly of a supportive nature, then, for example, in Germany, there is a special government program for the active development of rural territories (National Strategy for Rural Development of the Federal Republic of Germany, 2010). However, the measures for the development of rural areas in developed states and in the recommendations of international organizations are mainly aimed at retaining young people and creating new jobs in the field of services for rural residents and in sectors related to agriculture (forestry, agro-tourism). It is also important to develop education and innovation for the needs of the traditional sphere for rural areas - agriculture and agribusiness in general (Chekmarev et al., 2021; Pashkus, 2018). Despite the importance of these measures, it is necessary to take into account the limited nature of their impact due to relatively small volumes of demand and low potential for creating new jobs. According to the authors, more diverse areas of employment development are also required in rural areas, involving not only the local population, but also using the opportunities of immigrants from the cities.

The COVID-19 pandemic led to a global economic crisis, which, as it seems to the authors, created several additional incentives and opportunities for active and sustainable development of rural areas. Urban agglomerations have faced the significant problems associated with the spread of the coronavirus. The overload of health care systems, selfisolation regimes, the closure of many, primarily small enterprises, the need to transfer workers to remote employment, breaks in the logistics supply chains of global trade and restrictions on the movement of migrant workers at the international level are far from a complete list of these problems (Liu et al, 2021; Barcaccia et al., 2020). 
It cannot be said that the pandemic has bypassed rural areas. One of the most problematic situations here was the shortage of migrant workers for agricultural work (IOM, 2020). However, already in its first months, there are studies indicating that the rate of spread of morbidity in rural areas remote from the main foci of infection is more slow, relative to urban agglomerations (Healy, 2020; Fang, Wahba, 2020). Some studies indicate trends of higher morbidity among the population living around urban agglomerations and working in city centers (Density and Covid-19 in New York, 2020; Puzanov \& Bobrova, 2021). However, there are practically no studies of morbidity among truly rural residents. Taking into account the spread of forms of remote employment and in the framework of increasing the resilience of countries ' economies to the consequences of the pandemic, the question arises as to whether it is advisable to develop rural areas as buffer zones for the spread of infection and whether the pandemic has created additional incentives and opportunities for their development.

Thus, the purpose of this article is to assess the impact of the COVID-19 pandemic on the incentives and opportunities for sustainable rural areas development.

\section{Methods}

To fulfil this purpose, the first stage of the study to assess statistically the level of the pandemic spread in rural areas relative to urban areas. This is done based on comparison and statistical assessment of the differences significance in the incidence of COVID-19 in rural, urban settlements and regional centers one of the regions of Russia - the Leningrad Region. The choice of the region was determined by the availability of detailed and differentiated information with the possibility of analyzing the incidence in two periods (from the beginning of the pandemic to the end of the second Russian wave of coronavirus and to the middle of the third). This allows us to assess how long-term differences in the incidence of the population between urban and rural areas are.

At the second stage of the study, new incentives and opportunities for sustainable rural development are analyzed based on the study and extrapolation of the results obtained by researchers in the field of remote employment potential and a request for resettlement to rural areas from urban agglomerations.

\section{Results and Discussions}

Table 1 presents the processed statistical data on the accumulated incidence of COVID-19 in the Leningrad Region (one of the largest northwestern regions surrounding the second largest city in Russia-St. Petersburg). The Department of the Federal Service for Supervision of Consumer Rights Protection and Human Well-being in the Leningrad Region began collecting statistics on patients starting from 13.04.2020. The incidence rate was estimated on 01.03.2021 and 11.07.2021 among the population of rural settlements, urban and district centers in each of the 17 districts of the region. The calculations did not take into account a separate administrative district - the city of Sosnovy Bor due to the absence of a rural population there. 
Table 1. The level of morbidity in urban and rural areas of the Leningrad region, people per 1000 inhabitants 2020-2021.

\begin{tabular}{|l|l|l|l|l|l|l|}
\hline Districts & \multicolumn{3}{|c|}{ Ha 01.03 .21} & \multicolumn{3}{c|}{ Ha 11.07 .21} \\
\hline & $\mathrm{U}^{*}$ & $\mathrm{R}^{* *}$ & $\mathrm{D}^{* * *}$ & $\mathrm{U}^{*}$ & $\mathrm{R}^{* *}$ & $\mathrm{D}^{* * *}$ \\
\hline Leningrad Region & 20.09 & 17.60 & 26.56 & 28,46 & 24,89 & 36,92 \\
\hline Boksitogorsky municipal district & 24.96 & 15.76 & 31.74 & 35,89 & 21,14 & 48,37 \\
\hline Volosovsky municipal District & 24.86 & 20.13 & 24.86 & 39,74 & 32,02 & 39,74 \\
\hline Volkhovsky municipal district & 15.66 & 12.17 & 15.21 & 22,32 & 15,9 & 21,69 \\
\hline Vsevolozhsky municipal district & 18.54 & 16.95 & 24.41 & 27,47 & 24,23 & 34,58 \\
\hline Vyborg municipal District & 20.71 & 12.50 & 26.32 & 29,54 & 19,91 & 34,99 \\
\hline Gatchina Municipal District & 22.62 & 20.24 & 24.06 & 31,05 & 27,76 & 33,15 \\
\hline Kingisepp Municipal District & 19.78 & 13.53 & 20.15 & 26,29 & 19,82 & 26,87 \\
\hline Kirishsky municipal district & 32.29 & 20.50 & 32.80 & 40,49 & 28,02 & 41,05 \\
\hline Kirovsky municipal district & 13.83 & 12.47 & 16.59 & 19,72 & 18,61 & 22,95 \\
\hline Lodeynopolsky municipal district & 40.44 & 19.27 & 40.97 & 57,58 & 31,95 & 58,45 \\
\hline Lomonosovsky municipal district & 16.08 & 17.67 & - & 19,62 & 21,81 & - \\
\hline Luzhsky municipal District & 21.43 & 19.76 & 21.61 & 31,68 & 27,81 & 31,92 \\
\hline Podporozhsky municipal district & 30.41 & 40.39 & 32.08 & 39,92 & 48,73 & 40,6 \\
\hline Priozersky municipal district & 39.95 & 22.72 & 42.78 & 50,12 & 31,57 & 54,23 \\
\hline Slantsevsky municipal district & 30.56 & 16.29 & 30.56 & 47,5 & 27,06 & 47,5 \\
\hline Tikhvin municipal district & 28.75 & 26.89 & 28.75 & 41,18 & 31,39 & 40,18 \\
\hline Tosnensky municipal District & 14.38 & 14.56 & 18.87 & 21,44 & 21,09 & 26,83 \\
\hline & & & & \\
\hline & & & &
\end{tabular}

$* \mathrm{U}-$ Urban settlements ** R-Rural settlements *** D - District centers

Source: Department of the Federal Service for Supervision of Consumer Rights Protection and Human Welfare in the Leningrad Region, 2021

The data, placed in the table, clearly indicate the level of registered morbidity in rural settlements of the region districts is lower than in urban ones. The difference between rural communities and district centers is particularly clear, because the last ones, as a rule, have a higher population density than small towns and urban-type settlements located on the territory of the corresponding district. The table shows importance of testing the morbidity per 1,000 inhabitants in the Student's t-test. Testing empirical correlation between the number of cases persons per thousand and places of residence of the patients, calculated on the basis of the variances, shows moderate statistical relationship.

Thus, it is statistically proved, that there is a tendency to a relatively low incidence of coronavirus, relative to urban areas and especially district centers in the rural ares of the Leningrad region during two periods of time.

Slight differences in the morbidity rates in some areas of the region (for example, Lomonosovsky, Kirovsky, etc.) can be due to both the similar reasons, archive in the study 
on morbidity in New York (Fang \& Wahba, 2020), and the special features of the territorial organization. For example, Lomonosov is a city and the district center of the Lomonosovsky district, however, recently it has become part of Saint-Petersburg and therefore the incidence statistics for the largest city in the district is maintained by another department and is not taken into account in the above analysis. In some cases, statistical accounting is also complicated by the re-registration of settlements from urban to rural in connection with the implementation of the interests of local authorities. For example, the preferential credit programmes eligible only for the families living in the rural areas and has forced the local authorities to change status of localities for solving the problems in housing.

Of course, the presented data needs additional verification. It is useful to estimate the evolution of the general mortality rate in urban and rural areas in order to eliminate possible problems with the different rates of morbidity of the population living in different types of settlements. It is advisable to assess the change in the level of total mortality of the population in urban and rural areas in order to eliminate possible problems with different levels of morbidity of the population living in different types of settlements. However, taking into account the results of the above-mentioned studies on a slower rate of morbidity spread in rural settlements and with the confirmation of these trends in other regions of the country and foreign countries, it can be concluded that increasing the percentage of rural population helps to reduce the burden on the country's health system both in terms of slowing the rate of peak loads, and from the standpoint of the total required number of health services. It is a significant incentive for the state authorities to pay attention to the expediency of accelerated development of rural areas, taking into account new (or well-forgotten old) threats to epidemiological security and the preservation of the health of citizens.

However, the fact that the incidence rate in rural areas is lower in the context of a pandemic is not enough to deploy full-scale programs for their development. It was noted above that the question of the source of income and the place of work is the key question for the real retention and replenishment of the rural population. The state has the ability to finance infrastructure in the rural areas, but it is difficult to count both on the simultaneous financing and job creation (especially on an ongoing basis) and the construction of infrastructure facilities taking into account the more expensive investments in rural infrastructure. Nevertheless, it seems to the authors of this article, the pandemic has provided strong impetus for rural development as a broad global trend in creation of remote jobs. It cannot be said that the pandemic formed this trend in the labor market, but it sped up it many times is an obvious fact. According to McKinsey \& Company (2020), depending on the level of economic development of the country, from 5 to $22 \%$ of the workforce can work remotely from three to five working days a week. Especially since that employment in agriculture in developed countries is $1.5-2 \%$ of the total employment in the economy, even with the pre-pandemic request for rural resettlement (Zvyagintsev \& Neuvazhaeva, 2015), it is possible to increase the number of employed people in rural areas to a level at least comparable to employed in agricultural production, and three to four times more for developed countries.

At this scenario, measures for the development of the service sector in rural areas are updated, as the demands will increase provided by high incomes of remotely employed people living in rural areas. After all, the most promising jobs for transferring to remote work are those whose salaries are above the average level (finance and insurance, professional services, education, IT technologies). In addition to financial investments, remotely employed people can also bring new competencies to rural areas, that in general will promote the rural social capital. However, measures are needed to prevent conflicts between indigenous and new populations, the emergence and development of which can reduce the value of the noted effects. The scenario can be implemented most effectively in the long term only with the active participation of the state in the creation of industrial and social infrastructure in rural areas. First of all, this concerns the availability of communication 
services, transport and the road network, as well as housing and communal services in rural areas. Although in the short term, there is already a boom in housing in rural areas in Russia today. However, the short-term demand of population should be supported by the appropriate public policy.

In the long term, keeping of the population attached to the rural areas will also help to eliminate the risks of insufficient labor for agricultural work, especially seasonal work. After all, with the growth of the rural population and the acquisition of farming skills on the land, there is an internal labor potential that can be partly used into agricultural production. Although these processes will probably continue in parallel with the development of robotic technologies in agriculture.

\section{Conclusions}

Summing up the results of this study, we can draw the following main conclusions:

1. Primary data on the example of one of the regions of Russia indicate a lower level of morbidity during the pandemic in originally rural settlements in comparison with urban ones. This is especially pronounced in localities with a relatively low level of pendulum migration. This should encourage governments to develop rural areas to increase the resilience of economic systems to new epidemiological threats.

2. The spread of remote employment in the context of a pandemic and the one-and-a-halfyear adaptation of organizations to the use of remote workers, combined with the capabilities of modern technologies, are a strong incentive for a significant proportion of the urban population to move to rural areas.

3. Moving to rural areas of the population working remotely stimulates economic activity in rural areas through the enrichment of human capital and increasing demand for local goods and services, provided with income at the level of urban wages.

4. The problems of global migration during the pandemic encourage the governments of different States to look for internal reserves of labor potential to maintain the level of agricultural production and ensure food security, which is one more incentive for the development of rural infrastructure.

\section{References}

1. Angelov, N., \& Waldenström, D. (2021). COVID-19 and Income Inequality: Evidence from Monthly Population Registers. IZA Policy Paper, 178.

2. Barcaccia, G., D'Agostino, V., Zotti, A., \& Cozzi, B. (2020). Impact of the SARS-CoV2 on the Italian Agri-Food Sector: An Analysis of the Quarter of Pandemic Lockdown and Clues for a Socio-Economic and Territorial Restart. Sustainability, 12(14), Article 5651.

3. Brawn, J. \& Mirzabaev, A. (2016). Land use change and the economics of land degradation in the Baltic region. Baltijskij region, 8, 45-60.

4. Caunedo, J. \& Keller, E. (2021). Capital Obsolescence and Agricultural Productivity. The Quarterly Journal of Economics, 136(1), 505-561.

5. Chekmarev O. P., Kovalenko E. V., Sudorgina I. G., Timoshenko S. A., Lukichev P. M. (2021). Educational Innovation in the Digitalization of Agroindustry. In: Bogoviz A.V. (Ed.) The Challenge of Sustainability in Agricultural Systems. Lecture Notes in Networks and Systems, 205. Springer. 
6. Colucci, M., Palermo, A. \& Francini, M. (2015). The Sustainable Development of Rural Areas. Proceedings of the 2nd International Conference on Civil, Materials and Environmental Sciences. Atlantis Press.

7. Density and Covid-19 in New York. (2020, May). CHPC New York City. https://chpcny.org/wp-content/uploads/2020/05/CHPC-Density-COVID19-in-NYC.pdf

8. Department of the Federal Service for Supervision of Consumer Rights Protection and Human Welfare in the Leningrad Region. The total number of registered cases of COVID-2019 in the Leningrad Region from 13.04.2020 to 11.07.2021. (2021). http://47.rospotrebnadzor.ru/content/total-number-registered-covid-2019-in-theterritory-Leningrad-region-is-1

9. Fang, W., Wahba, S. (2020). Urban Density is not an Enemy in the Coronavirus Fight: Evidence from China. World Bank Blog, https://blogs.worldbank.org/sustainablecities/urban-density-not-enemy-coronavirusfight-evidence-china

10. FAO (2018, October). Increasing the attractiveness of rural areas for young people. http://www.fao.org/about/meetings/coag/coag-26/documents/ru/

11. Healy, J., Tavernise, S., Gebeloff, R. and Cai, W. (2020). Coronavirus Was Slow to Spread to Rural America. Not Anymore. The New York Times. https://www.nytimes.com/interactive/2020/04/08/us/coronavirus-rural-americacases.html

12. IOM (2020). Migrants \& global food supply (COVID-19 Analytical Snapshot No. 18) https://www.iom.int/migration-research/covid-19-analytical-snapshot

13. Kuroda, N. (2019). Conservation Design for Traditional Agricultural Villages: A Case Study of Shirakawa-go and Gokayama in Japan. Built Heritage, 3, 7-23.

14. Land Use (2021). FAOSTAT http://www.fao.org/faostat/en/\#data/RL

15. Lang, L. D., Behl, A., Dong, N. T., Thu, N. H. \& Dewani, P. P. (2021). Social capital in agribusiness: an exploratory investigation from a supply chain perspective during the COVID-19 crisis. The International Journal of Logistics Management.

16. Liu, N., Xu, Z., \& Skare, M. (2021). The research on COVID-19 and economy from 2019 to 2020: analysis from the perspective of bibliometrics. Oeconomia Copernicana, 12(2), 217-268.

17. McKinsey \& Company (2020). What's next for remote work: An analysis of 2,000 tasks, $800 \mathrm{jobs}$, and nine countries. https://www.mckinsey.com/featured-insights/future-ofwork/whats-next-for-remote-work-an-analysis-of-2000-tasks-800-jobs-and-ninecountries\#

18. Medouz, D., Randers, J, Medouz, D. (2007). Predely rosta. 30 let spustja [Growth limits. 30 years later]. M.: IKC Akademkniga.

19. Ministry of Economic Development of the Russian Federation. (2021). http://old.economy.gov.ru/minec/press/news/doc20111208_004

20. National Strategy for Rural Development of the Federal Republic of Germany (2010) https://agrardialog.ru/files/prints/razvitie_selskih_territoriy_v_germanii_rus.pdf

21. Pashkus, N. A. (2018). Breakthrough positioning of innovative products in the global economy: approaches and problems. Globalization and its socio-economic consequences: Proceedings, Rajecke Teplice. Slovak Republic. 2282-2291.

22. Puzanov, A. S., Bobrova, K. V. (2021). Cities on the front line of the fight against coronavirus - an overview of the international expert agenda and an assessment of its adequacy to Russian realities. Institute of Urban Economics. 
http://www.urbaneconomics.ru/research/mind/goroda-na-peredney-linii-borby-skoronavirusom-obzor-mezhdunarodnoy-ekspertnoy

23. Rosstat (2021). http://www.gks.ru

24. Sauter, I., Kienast, F., \& Bolliger, J. (2019). Changes in demand and supply of ecosystem services under scenarios of future land use in Vorarlberg, Austria. Journal of Mountain Science, 16, 2793-2809.

25. Wosiek, M. (2020). Rural-urban divide in human capital in Poland after 1988. Oeconomia Copernicana, 11(1), 183-201.

26. Zvyagintsev, V. I., Neuvazhaeva, M. A. (2015). Migrants from the city to the rural area: the phenomenon of "reverse migration" in modern Russia. http://cyberleninka.ru/article/n/pereselentsy-iz-goroda-v-selskuyu-mestnost-fenomenobratnoy-migratsii-v-sovremennoy-rossii 